\title{
THE ASPECTS OF TRUMP'S CHINA STRATEGY
}

\section{MARKO PAVICEVIC \& ANTONIS POLENTAS}

School of Political Science and Public Administration, Shandong University, Shandong, China

\begin{abstract}
This article assesses new American administration foreign policy of Trump s presidency. In an interesting turn of the events, Trump is pursuing the policy of engagement toward China with the win-win cooperation approach. Although we can see unilateral tendencies in new administration foreign policy, new norms are being created by president Trump, which indicates thata high level of engagement is necessary in order to deal with issues in East Asia in general and China in particular. President Trump's administration is shifting US foreign policy from liberal hegemony to a more narrow focus on the US national interests. This shift is expected to pose more challenges for China, but also to create more opportunities.
\end{abstract}

KEYWORDS: Engagement, Norms, Populism, Nationalism, Trump \& China

Received: Oct 14, 2018; Accepted: Nov 04, 2018; Published: Nov 15, 2018; Paper Id.: IJPSLIRDEC20182

\section{INTRODUCTION}

Minxin Pei, in his interview for Project Syndicate, characterized Trump as "a shock to the world". Shock is something that creates instability; when there is instability, investors are afraid to invest capital, shares at stock exchange indexes plummet and conflicts and tensions can occur unpredictably. In other words, Trump's administration is expected to cause discontinuities in world politics and break away from the Foreign Policy (FP) practices of previous post-Cold War presidents ${ }^{1}$. That is happening right now in the Unites States and the West, where ideas of neoliberalism and globalization are starting to be perceived as something that has contributed to growing inequality where one side acquired the lion share of profits at the expense of others. Trump came as a saviourof the American common people against globalization and corrupted establishment where Hillary Clinton belongs by promising that he would not forget those that had been neglected by liberal progressivists. He also said that NATO is obsolete, that other countries are taking advantage of the United States bybandwagon and free-riding at their expense. For all these accusations, it is not sure do they belong to the real facts or alternative facts ${ }^{2}$.

Of the 2016 electoral campaign Trump and his associates have endorsed and promoted a narrative of China as a threat to US interests and ultimately as a malign contender of primacy in world affairs. This narrative is a lynchpin of his wider narrative of the US as a declining power who is losing its "greatness" due to the disastrous policies of previous administrations who opted for constructive engagement and often for accommodation with

\footnotetext{
${ }^{1}$ In spite of clear differences between Clinton, G.W. Bush and Obama FPs, it has been argued that they can be characterized as falling in the spectrum of a FP that pursues "liberal hegemony" (Mearsheimer 2018). Trump's tensed relatiosn with some of the US traditional allies like Japan and Germany, while getting on well with Russian president Putin and the North Korean dictator Kim Jong-un are indications of breaking away from the FP of his predecessors.

${ }^{2}$ Fact is something that exists as reality and is justifiable by empirical findings where alternative facts represent delusion which is opposite of reality and represents untruth.
} 
China.

As every other president, Trump has tried to impose its vision that he thinks it is the best for the American people, but "obvious argument is that the constraints imposed by domestic politics and the external environment are strong enough to limit the ability of any president to implement a vision that sharply breaks from the past" (Jervis, 2017 p. 2). Furthermore, President Obama was asked on how possible it is to radically change your foreign policy; his answer was, “Once you're in the Oval Office, once you begin interacting with world leaders, once you see the complexities of the issues, that has a way of shaping your thinking" (Miller \& Rogin, 2016).

United States faces the biggest challenge in last 40 years and that is the dynamism of China`s economic rise that has broad geopolitical implication for both Unites States and its allies and "[...] with just 4.4\% of the world's population and a falling share of world output, the US might try to hang on to its delusion of global dominance through a new arms race and protectionist trade policies. Doing so would unite the world against US arrogance and the new US military threat. The US would sooner rather than later bankrupt itself in a classic case of imperial overreach" (Sachs, 2016, para. 13).

The purpose of this paper is to explain Trump`s strategy towards China. It is divided into two sections. The first one presents a holistic approach to Trump`s China strategy that includes economic, diplomatic and security elements. The second one addresses Trump`s neoconservative turn with a Jacksonian ${ }^{3}$ flavour and how that affects and complements relations with China. The argument will be that the U.S. turn to neoconservative strategy and unilateral approach did not harm longstanding approach of engagement.

\section{TRUMP'S ECONOMIC, DIPLOMATIC AND SECURITY STRATEGY TO CHINA}

At first, the world was completely confused with Trump'slack of clear statement on US FP and the incongurence between various views he had expressed during his campaign and the "liberal hegemony" FP views of his recent predecessors (Mearsheimer, 2018). He was arguing that the U.S. should not continue to serveas theglobal policeman and it was not their job to solve problems around the world, but at the same time he never rejected the idea that the U.S. is the most powerful country in the world. In relation to that, Deng (2017, para. 7) commented that "Trump sees US hegemony as a burden, and seems oblivious to the privileges that it affords, not least the many benefits associated with controlling the world's main reserve currency. But, at the same time, Trump does not want to cede America's global preeminence, which means that he could show a penchant for trade wars, or even military conflicts". Then, the imminent came that was previously argued by president Obama that reality will change Trump`s attitude and one of the first things Trump did was strengthening American military in EU, increasing and reassuring cooperation with Japan and South Korea, pursue deployment of Terminal High Altitude Area Defense system in South Korea while, instead of disrespecting one China policy, Trump adopted more rational and pragmatic stance (Chengde, 2017).

Trump representsthe neoconservative faction of the Republican Party that use hawkish rhetoric in campaign, usually against countries like China and when they come to power they behave like Democrats (Thompson, 2016). It is not that Trump is behaving like Obama but it seems that Trump`s administration accepts dynamics that was put forward by President $\mathrm{Xi}$ in 2012, i.e.the principles of no conflict, no confrontation, mutual respect, and win-win

\footnotetext{
${ }^{3}$ Term named after president Andrew Jackson whose rhetoric was that U.S. should not try to destroy evil countries abroad but to intervene only where there is self interest.
} 
cooperation because these principles were repeated by secretary Tillerson while visiting China (Wenzhao, 2017). According to Gaoyue (2017, para. 3) "The acceptance of the principle has at least achieved three effects: mutual suspicion decreases, mutual trust increases; consensus increases, divergence decreases; desire to cooperate increases, willingness to confront decreases. With such a foundation China and the US have no reasons not to expand their cooperation”.

This section will first look at economic and trade approach to China that went from aggressive isolationist rhetoric to traditional engagement that was justified by security concerns. Furthermore, diplomatic engagement especially the meeting at Mar-a-LagoinFlorida between president Trump and president Xi shows further engagement while respectfully addressing differences. Security approach to Asia Pacific remains similar to Obama`s apart from the fact that Trump`s is engaging China more on Korean issue that further indicates an engagement approach.

\section{CURRENCY AND TPP}

Trump represented a departure from all previous mainstream politicians, both Democrat and Republican. $\mathrm{He}$ is a true mercantilist who sees trade as a zero sum game where surpluses of the country are not based on competitiveness but on unfair competition. Beside the fact that the United States economy is performing well, where GDP is on the rise and unemployment has dropped below 5 percent, Trump ran a campaign based on "America first" rhetoric (Mildner\&Schmucker, 2017).

One direct reason that improved relation between China and U.S. is that Trump will not declare China a currency manipulator. At the beginning of his presidency Trump argued that he would label China currency manipulator beside the fact that China had been investing billions of dollars in the last couple of years to appreciate the Renminbi and People's Bank of China intervention was aiming at strengthening, not weakening, the currency (Jun, 2017). According to Neil Irwin, currency is not an issue and the U.S. should focus more trade deficit and not be distracted by "small issues". However, Trump does not think as an economic expert, but like a pragmatic businessman, so he justifies his argument as strategically good in order to convince China to help U.S. with issues like North Korea (Davidson, 2017). Of course, we can argue that Trump did have some success in that since China suspended coal shipments from North Korea (Liptak, 2017).

A second, indirect, reason for improved relation between China and U.S. and indicator that Unites States appeared not endorsing an approach of containing China is withdrawal from Trans Pacific Partnership (TPP). “On October 5, 2015, Ministers of the 12 Trans Pacific Partnership (TPP) countries announced the conclusion of their free trade agreement (FTA) negotiations. The agreement is one of the Obama Administration's signature trade policy initiatives, an effort to reduce and eliminate trade and investment barriers and establish new rules and disciplines to govern trade and investment among the 12 countries”. (Dolven et al., 2016, p. 1). Many theorists explain this initiative as balancing phenomenon where Unites States uses TPP as a tool to balance against the rise of China (Hamanaka, 2014). Obama saw this as an opportunity to pursue multilateral framework against China that might hurt the U.S. economy in the short run but in the long turn it can create a form of "miniregionalism", where the United States can promote their valuesand create norms that others will follow. "Constructivists have long argued that normative change is possible through strategic actors acting as norm entrepreneurs or revisionist, altering the normative structure of international society over a period of time" (Jackson \& McDonald 2014, p. 8). Beside the traditional economist who argue that economic regionalism is good for the country in the long term because it brings countries together, Trump is altering the normative structure of both domestic and international societies (in this case for American society) by arguing that TPP will hurt American workers and undercut American 
companies (Subramanian, 2016).

Besides the unorthodox neoconservative turn and Jacksonianflavourin American foreign policy that arrived with Trump, which entails aggressive persuasion of American interest without promotion of democracy and free trade and highly unusual skepticism of traditional partners, not labeling China as a currency manipulator shows that there is a high level of engagement with China and not pursuing Trans Pacific Partnership shows that Trump does not have a multilateral approach against China.

\section{DIPLOMACY}

It is very difficult to pinpoint the characteristics ofthe USFP since Trump took over. What can be argued is that based on his populist slogans during the electoral campaign and the first months of his presidency, it is expected to see a decisive turn towards a more US-focused FP as more recent events like the imposition of tariffs on imports from a variety of states, notably China. Trump's unexpected moves and his style have tended to keep Chinese leaders on the defensive as the lack of decisive reactions from their side suggests (Council on Foreign Relations, 2018). If we take into consideration his populist and isolationist tendencies we can argue that the U.S. might reduce its global policemen tendencies or perform it selectively and while its partner's shoulder significantly higher economic burden. If the U.S. decides to push thepolicy of primacy against China to its extremes, it is going to be very counterproductive for the world economy and it has already spread concerns among traditional US allies. China wants to be accepted as a joint rule maker and not just someone who blindly follows the rules, and this is legitimate demand having in mind the increasing power and influence (Evans, 2016).

Diplomatic engagement between China and U.S. in the first hundred days of Trump`s presidency went from an extremely hawkish and aggressive to an increasingly engaging diplomatic and respectful stance. At first, Trump accused China of currency manipulation and of taking American jobs while Rex Tillerson argued that "China should be denied access to islands, it has built in the contested South China Sea" (Brunnstrom \& Spetalnick, 2017, para. 1). The first diplomatic turn was when Tillerson visited China and repeated the words of President Xi, which are the principle of no conflict, no confrontation, mutual respect, and win-win cooperation, phrasing that was never completely repeated by the Obama administration (Wang, 2017). Acknowledging these principles gave a complete new diplomatic vibe that gave the impression it could take China - U.S. relation to a new positive level.

The Xi-Trump summit was an important point that is expected to set the course, whether negative or positive. The two countries have very different needs and desires so it is difficult to imagine an easy diplomatic discourse. Trump said that the meeting would be a very difficult one (Huiyao, 2017) but "for China's part, Trump has already provided three things it craves: reaffirmation of the One China Policy, no unilateral punitive economic measures, and the symbolic 'face' accorded to Xi Jinping as a world leader" (Shambaugh, 2017). Of course, China wanted more than that, but tostart this is setting a positive agenda for further development. The two leaders met for the first time and even though the meeting was "overshadowed by the biggest military action of Trump`s presidency" (Berlinger, 2017, para 7), meeting went very positive and with acknowledgement ofmutual respect and understanding. Two very sensitive issues were on the agenda: a) the economy and b) the North Korea. The two leaders agreed on a 100-day plan to discuss trade talks directed at boosting US exports and reducing Washington's trade deficit with China, according to Commerce Secretary Wilbur Ross. Given the range and the magnitude of the issues under consideration, that may be ambitious, but it is a very big sea of change in the pace of discussion ("Trump to make China state visit", 2017). 
Regarding North Korea, the two leaders agreed that the situation is very unstable and that together they need to address the issues together. Furthermore, another member of the cabinets clearly showed that the Korean issue is dealt together with China; Lt General HR McMaster stated that there is consensus with China that the situation cannot continue like this, while U.S. Defense Secretary James Mattis said that they were working closely with China to engage North Korea.

We are witnessing a neoconservative turn in the USFP where he does not hide unilateral tendencies in solving problems. Recent examples of this tendency include the issue of North Korea, where Trump said that it will talk to the Chinese president about North Korea, but if the latter does not wish to help towards finding a solution, the U.S. would act alone. ("US will act alone on North Korea if China fails to help", 2017). "Public diplomacy, like constructivism challenges the primacy of material power in achieving outcomes, and offers an alternative model of practice that understands the normative or ideational structures underpinning audience identities and gains influence by engaging through the shared understandings of this inter-subjective dimension, including through social interaction and interplay" (Byrne 2012, para. 3). This what is exactly what Trump has been doing, i.e. he is using the power of the military to show that the U.S. has capabilities to solve the problem on its own if needed. In the same time, it is engaging in inter-subjective discourse with the Chinese president regarding what will be the best approach to deal with North Korea while understanding the other side's point of view and above all respecting it.

\section{SECURITY}

In similar lines with Obama, Blackwill (2017) argues the same as Barack Obama, i.e. that the U.S. should not turn its back on Asia-Pacific and that not proceeding with the TPPinitiative is a bad decision. Furthermore, the time for engaging and hedge is over and that the U.S. needs to engage and contain China through investing in military and alliances that enable power projection. Trump, at first, had arguments that the U.S. was not responsible for fixing all the problems around the world and he even made a comment that South Korea and Japan needed to invest more on their defense capabilities in order to deter North Korea's aggression. This led people to believe that "he may be backing into a realistic assessment what is needed to pursue an effective national-security policy" (Zakheim, 2017, p. 2) but he is not turning to realist FP, only to a neoconservative one. Mearsheimer (2005) argues that neoconservatives believe in very strong military power of the U.S. and that power should be used to serve their interests. Furthermore, neoconservatives favoura unilateral approach and they believe in a bandwagoning logic where the U.S. uses its powerful military and others then acknowledge that the United States has serious intentions. We can see these arguments in practice where Trump unilaterally decided to send missiles to Syria without consulting first with partners, which had a point to make in East Asia that the U.S. under the new administration means business. As a neo-conservative Trump probably thinks that by showing of military power in Syria, others will bandwagon with the U.S. against North Korea.

First, Trump's U-turn on security strategies came into play when he sent the Secretary of Defense James Mattis to Japan and South Korea to deliver the message that the U.S. will maintain alliances while sending the a clear signal to North Korea (Reynolds \&Syeed, 2017). Furthermore, Rex Tillerson's first visits abroad werein Japan and then to South Korea with the purpose to reassure the U.S. allies that the U.S. stands behind them against the North Korea. ("Rex Tillerson begins tense China meetings", 2017). Not that Trump continued business as usual foreign policy, but it took it to another level by announcing THAAD deployment in South Korea. United States is realizing that multilateral alliance is not succeeding in East Asia so THAAD is the only way to project power, which will by the way have negative consequences 
and it will create security dilemma (Gaoyue, 2017). Continuation in already established foreign policy can be seen regarding South China Sea where in February, Trump showed a tougher stance on South China Sea by sending US navy carrier strike group led by the USS Carl (Xiangmiao, 2017). I argue that this does not represent tougher stance in South China Sea compared to the Obama administration, it is just a continuation of military show off with the purpose of defending interests and not loosing face.

Before the 2016 Presidential elections, Jackson (2015) argued that a Trump victory would be a disaster in Asia. Firstly, he argued that Trump would abandon alliances in Asia, which he thought as very bad because the U.S. served as a stabilizing factor. He opined that, without the U.S. involvement, other countries would increase their defense expenditures which would lead to the destabilization of the region. First of all this never happened and Trump never initiated action that entails U.S. leaving Asia and second of all other countries are investing heavily in military even though the U.S. was there the whole time.

Compared to previous administrations Trump is not pursuing a multilateral approach toward China. Trump did continue a similar security strategy in Asia as previous administrations but with different characteristics. Trump`s administration is increasingly engaging with China in solving the problem of North Korea which shows that they "can overcome that stalemate by highlighting the social aspect of the security dilemma such as mutual understanding of the mutual identity and acknowledging each other`s interests and core security" (Mohammad, 2011). Acknowledging the social aspect of security dilemma can be seen in the Trump-Xi summit where president Xi explained to Trump what would happenin their boarder in case the North Korean regime collapsed and president acknowledge that through China`s interest and core security.

\section{TRUMP'S VERSION OF NATIONALISTIC (US-FOCUSEDO POPULIST FP AND ENGAGEMENT OF CHINA}

In the theory of International relations, there are no specific guidelines such as one for realism, liberalism or constructivism to explain neoconservative foreign policy and "term neoconservative has never represented a coherent and unified political construct; there was no central link between the various political ideas that characterize the positions held by those thinkers typically identified with neo-conservatism. The centrifugal forces within the neoconservative community have typically been predominant, until the movement is mobilized by the awareness of an enemy" (Dusanic\&Penev, 2009, p. 91). Furthermore, “...the early neoconservatives sought to reorient the Unites States domestic politics by harnessing the readymade moral foundations that religion provided, without necessarily being religious themselves" (McGlinchey, 2010, p. 22). Practically speaking, they support the free market economy and a strong military that entails a large increase in defense budget, support the idea that the U.S. should be a global policeman and since they prefer the unilateral approach against multilateral approach, they are skeptical toward international institutions (Soltani\&Yusoff, 2013).

We can finally argue that Trump is not isolationist (even though all campaign promises and speeches had an isolationist flavour) and that he will care about what is happening outside the U.S. in cases where the US interests are in danger.The views dominant in his administration point to an extreme securitization of China's growth, especially as it was depicted by President Xi Jinping in the $19^{\text {th }}$ Congress of the Chinese Communist Party in the fall of 2017. Trump promised to the American people economic nationalism in domestic politics and isolationism in foreign politics buthis moves show that it is very unlikely that his campaign promises will fully materialize. Hehas taken many U-turns since in the first year of his administration and he even made it clear at the Center of National Interest that the world is a safer place when 
America is united and strong. On the one hand, there are those who argue that he is not a true neoconservative because he is not talking about democracy and human rights, but he is a true Jacksonian that is willing to use power only when the national interests of the United Statesare being questioned (Lowry, 2017). Trump is embracing Bush`s neoconservative foreign policy, butwe argue that it is a nationalist neoconservative turn that does not have the aim of promoting democracy but American higher interest. Furthermore, we see a Jacksonian tendency, which is not destroying evil states but promoting American interests (Stepman, 2017).Trump is a combination of populism and the US-centered nationalism (“America First") two where he follows an isolationist (nationalistic) approach by showing skepticism toward international institutions and pushing for more unilateral approach while all this is being justified by foreign enemies that happens to be non-Christians. On the other hand, he is Jacksonian in nature by believing like realists that the arena of international politics is violent and anarchic, so there is no need to promote democracy, American values and that the U.S. should only interfere when its national interests are at stake. No theory, initiative, guidelines of political construct can by itself offer a comprehensive accountof a c'untry'sFP but rather a combination of themis required. If the country`s foreign policy is influenced by neoconservative principles that favour unilateralism, it does not necessarily mean that a particular country does not cooperate with other countries to solve problems. A good example of this is the Sino-US engagement to solve the crisis in the Korean peninsula.

The neoconservative tendency of the new administration can be seen in two occasions. One is in the statement of a new secretary of state Tillerson where he "warned that a pre-emptive US military strike against North Korea was an option and said Washington's "strategic patience" with Pyongyang had run out" (Phillips, 2017) and the other is President Trump`s statement that he would like very much China to help but if not U.S. would act alone. But since the meeting in Mar-a-Lago, it seems that the issue of the Korean peninsula is dealt through engagement between China and U.S. China supported new sanctions against North Korea and stopped importing coal from them. Despite the unilateral tendencies, Unites States is aware that it cannot fix the Korean peninsula problem byitself and it needs help from China. China and the Unites States can work together on this problem because they both want different things from each other. Unites States want North Korea who is not capable of obtaining ballistic missiles that can reach California and China wants the continuation of the same trade policies with the United States. These two countries can work together by acknowledging their different needs and by respecting their cultural differences. The problem at Korean peninsula is not fixed yet, but what is important is that both parties are working together to find a peaceful solution.

\section{CONCLUSIONS}

Trump`s FP is definitely something non-mainstream to both liberal progressivists and conservative Republicans. He does not focus much on democratic values, but he also pledges to protect South Korean and Japan from North Korea and which definitely shows the implication of normative tendencies despite the that the U.S. should intervene only when its interests are at stake. Maybe Trump is just following the good old advice from Morgenthau (1949) that a foreign policy based on moral principles is national suicide, i.e. he is following a hard-cord realpolitik FP according to which prioritizing moral principles equals to national suicide ${ }^{4}$.

Trump`s strategy toward China should be looked at from a holistic constructivist perspective where "identity

\footnotetext{
${ }^{4}$ An explicit instance of this stance is Trump's reaction to the mounting evidence that Saudi Arabia was behind the assassination of Jamal Khashoggi, where he stated that it would be inconceivable to risk the benefits the US reaps from arms sales to Saudi Arabia because of the alleged murder of a US citizen by Saudi agents (Embury-Dennis, 2018).
} 
formation at both internal and international levels is a continuous process in which both corporate and social identities interact with each other and hereby states produce and reproduce new definitions of self and other" (Mohammad, 2011, p. 282). Identity formation at the local level is made through the political establishment with neoconservative tendencies that the U.S.should act unilaterally to promote interest around the world.On the other hand, at the same time international level is shaping domestic policy as well where the Unites States is realizing that without Chinese help they cannot solve the crisis in the Korean Peninsula. These two sides of the coin lead Unites States to adopt a policy of engagement toward China.

\section{REFERENCES}

1. Berlinger, J. (2017, April 7). Trump-Xi summit overshadowed by US strike on Syria. CNN Politics. Retrieved from: http://edition.cnn.com/2017/04/07/politics/xi-trump-summit-syria/

2. Blackwill, R. (2017, March). America needs and "engage and contain" strategy for China. The National Interest. Retrieved from: http://nationalinterest.org/feature/america-needs-engage-contain-strategy-china-19791

3. Brunnstrom, D., \&Spetalnick M. (2017, January 2017). Tillerson says China should be barred from South China Sea islands. Reuters. Retrieved from:https://www.yahoo.com/news/trump-secretary-state-nominee-china-denied-access-south002043309.html

4. Byrne, C. (2012). Public diplomacy and constructivism: a synergistic and enablingrelationship. Paper presented at the meeting of International Studies Association Annual Conference at Bond University, San Diego.

5. Chengde, Y. (2017, March 27). Trump`s Foreign Policy: Old Wine in a New Bottle? China US Focus. Retrieved from: http://www.chinausfocus.com/foreign-policy/trumps-foreign-policy-old-wine-in-a-new-bottle

6. Council on Foreign Relations. (2018). 'The Third Revolution: Xi Jinping and the New Chinese State' by Elizabeth C. Economy [Video file]. Retrieved from: https://www.youtube.com/watch? $v=x x o b E o u W 2 T E$

7. Davidson, P. (2017, April 16). Trump defends u-turn on China`s currency manipulation.USA Today. Retrieved from:https://www.usatoday.com/story/money/2017/04/16/trump-defends-u-turn-china-currencys-practices/100548546/

8. Deng, Y. (2017, March 20). Can China save the global order? Project Syndicate. Retrieved from: https://www.projectsyndicate.org/commentary/china-leader-global-order-by-yong-deng-2017-03

9. Dusanic, A., \&Penev, P. (2009). The influence of the neoconservative movement on U.S.foreign policy. The Quarterly Journal, 8 (2), 91-100.URL: http://www.jstor.org/stable/26326171

10. Dolven, B., Fergusson, I., Manyin, M., Martin, M., Morrison, W., Williams, B. (2016).The trans pacific partnership: strategic implications. Washington, DC: CongressionalResearch Service. Retrieved from: https://fas.org/sgp/crs/row/R44361.pdf

11. Embury-Dennis, T. (2018, November, 3). Khashoggi murder: Trump administration 'devoid of moral foundation' killed journalist's fiancé says. The Independent. Retrieved from:

https://www.independent.co.uk/news/world/americas/khashoggi-murder-trump-administration-hatice-cengiz-saudi-arabiambs-journalist-a8616051.html

12. Evans, G. (2016, November 12). Preparing Asia for Trump. The Guardian. Retrieved from: https://www.projectsyndicate.org/commentary/trump-asia-australia-by-gareth-evans-2016-11

13. Gaoyue, F. (2017, March 15). Iron curtain rises with THAAD in South Korea. China US Focus. Retrieved from: http://www.chinausfocus.com/peace-security/iron-curtain-rises-with-thaad-in-south-korea 
14. Gaoyue, F. (2017, April 5). Xi-Trump summit will lead to comprehensive cooperation. China US Focus. Retrieved from: http://www.chinausfocus.com/foreign-policy/xi-trump-summit-will-lead-to-comprehensive-cooperation

15. Hamanaka, S. (2014). Trans pacific partnership versus regional comprehensiveeconomic partnership: control of membership and agenda setting [No. 146]. Manadaluyong, Philippines: AsianDevelopment Bank. Retrieved from:

https://www.adb.org/sites/default/files/publication/152753/reiwp-146.pdf

16. Huiyao, W. (2017, April 5). How a Xi-Trump summit could yield progress. Financial Times. Retrieved from: https://www.ft.com/content/d8d77238-19de-11e7-a266-12672483791a

17. Irwin, N. (2017, April 6). How Trump can improve the messy U. S. - Chinese economic relationship. The New York Times. Retrieved from: https://www.nytimes.com/2017/04/06/upshot/how-trump-can-improve-the-messy-us-chinese-economicrelationship.html?_r=0

18. Liptak, K. (2017, April 16). Trump defends about-face on labeling China a currencymanipulator. CNN Politics. Retrieved from:http://edition.cnn.com/2017/04/16/politics/donald-trump-china-currency-manipulators/

19. Jackson, R., \& McDonald, M. (2014). Constructivism, US foreign policy, andcounterterrorism. In Parmar, I., Miler, L. B., Ledwidge, M. (eds.), Obamaand the world: New directions in US foreign policy. New York: Routledge.

20. Jackson, V. (2015, September 11). Donald Trump`s Asia Policy Would be a Disaster. The Diplomat. Retrieved from: http://thediplomat.com/2015/09/donald-trumps-asia-policy-would-be-a-disaster/

21. Jervis, R. (2017). America and the world - 2017 and beyond. ISSF Forum. Retrieved from: http://issforum.org/ISSF/PDF/Policy-Roundtable-1-5B.pdf

22. Jun, Z. (2017, March 15). Trump`s Imaginary enemy. Project Syndicate. Retrieved from: https://www.project-syndicate.org/commentary/trump-china-accusations-currency-manipulation-by-zhang-jun-2017-03

23. Lowry, R. (2017, April 18). No, Trump is not neocon. National Review. Retrieved from: http://www.nationalreview.com/article/446821/donald-trump-syria-not-a-neocon

24. McGlinchey, S. (2010). Neoconservatism and American Foreign Policy. Politikon: The IAPSS Journal of Political Science, 16 (1), 21-34. Retrieved from: http://iapss.org/politikon/home.html

25. Mearsheimer, J. (2005). Hans Morgenthau and the Iraq war: realism versus neo-conservatism. open Democracy. Retrieved from: https://www.opendemocracy.net/democracy-americanpower/morgenthau_2522.jsp

26. Mearsheimer, J. (2018). The great dellusion: Liberal dreams and international realities. London, UK: Yale University Press.

27. Miller, A., \&Rogin, A. (2016, November 20). Obama tells the world not to prejudge Trump`s policies before he takes office. ABC News. Retrieved from:

http://abcnews.go.com/Politics/obama-tells-world-prejudge-trumps-policies-takes- office/story?id=43677921.

28. Mildner, S., \& Schmucker, C. (2017, March 30). America first. Berlin Policy Journal. Retrieved from: http://berlinpolicyjournal.com/america-first/

29. Mohammad, M. (2011). Title: a holistic constructivist approach to Iran`s foreign policy. International Journal of Business and Social Science, 2 (4), 279-284. Retrieved from:

http://ijbssnet.com/journals/Vol._2_No._4;_March_2011/31.pdf 
30. Morgenthau, H. (1949). The primacy of national interest. The American Scholar, 18 (2), 207-212. URL: http://www.jstor.org/stable/41205156

31. Phillips, T. (2017 March 18). Donald Trump anti-China tweet gives Rex Tillerson a freshwall to climb. The Guardian. Retrieved from: https://www.theguardian.com/us-news/2017/mar/18/donald-trump-anti-china-tweet-gives-rex-tillerson-afresh-wall-to-climb

32. Raynolds, I., \& Syeed, N. (2017, February 1). Trump Pentagon chief Mattis Seeks to reassure allies on east Asia trip. Bloomberg Politics. Retrieved from: https://www.bloomberg.com/politics/articles/2017-02-01/trump-s-pentagon-chief-seeksto-steady-allies-on-east-asia-trip

33. Rex Tillerson begins tense China meetings with Wang Li. (2017, March 18). BBC. Retrieved from: http://www.bbc.com/news/world-asia-china-39313654

34. Sachs, J. (2016, December 29). Learning to love a multipolar world. Project Syndicate. Retrieved from: https://www.projectsyndicate.org/commentary/multipolar-world-faces-american-resistance-by-jeffrey-d-sachs-2016-12

35. Shambaugh, D. (2017, March 31). What to expect from the Xi-Trump summit? China US Focus. Retrieved from: http://www.chinausfocus.com/foreign-policy/what-to-expect-from-the-xi-trump-summit

36. Soltani, F., \&Yusoff, M. (2013). Neo-conservatism in foreign policy of the Unites States. Research Journal of International Studies, 25, 102-108. Retrieved from: http://www.eurojournals.com/international_studies.htm

37. Stepman, J. (2017, April 2017). Trump`s America first policy will woo Jacksonianism. The National Interest. Retrieved from: http://nationalinterest.org/feature/trumps-america-first-policy-will-woo-jacksonians-20253

38. Subramaniam, V. (2016, November 25). Here`s why Trump hates the Trans-Pacific Partnership so much. Business Insider. Retrieved from: http://www.businessinsider.com/heres-why-trump-hates-the-trans-pacific-partnership-so-much-2016$11 ? I R=T \& r=U S \& I R=T$

39. Thompson, J. (2016, December 21). Hawkish republican campaign rhetoric. E-International Relations. Retrieved from: http://www.e-ir.info/2016/12/21/trump-china-and-the-history-of-hawkish-republican-campaign-rhetoric/

40. Trump to make China state visit, says top US diplomat. (2017, April 7). BBC News. Retrieved from: http://www.bbc.com/news/world-us-canada-39535828

41. US will act alone on North Korea if China fails to help, Trump says (2017, April 3). The Guardian. Retrieved from: https://www.theguardian.com/us- news/2017/apr/02/donald-trump-north-korea-china

42. Puślecki, Z. W. The regional innovation systems in the strategy of the european union's economic growth-europe 2020.

43. Wenfeng, Wang. (2017, March 31). Deals, not words, will shape US policy toward China. US China Focus. Retrieved from: http://www.chinausfocus.com/foreign-policy/deals-not-words-will-shape-us-policy-toward-china

44. Wenzhao, T. (2017, March 24). Tillerson's visit to China reduces uncertainties. China US Focus. Retrieved from: http://www.chinausfocus.com/foreign-policy/tillersons-visit-to-china-reduces-uncertainties

45. Xiangmiao, C. (2017, March 10). The south China sea in the Trump era. China US Focus. Retrieved from: http://www.chinausfocus.com/peace-security/the-south-china-sea-in-the-trump-era

46. Zekheim, D. (2017, March 18). Is Donald Trump a realist? The National Interest. Retrieved from: http://nationalinterest.org/feature/donald-trump-realist-19810?page=2 